\title{
Identification and Pathogenicity of Phytopathogenic Bacteria Associated with Soft Rot Disease of Girasole Tuber
}

\author{
Mamdoh Ewis ISMAIL ${ }^{1}$, Montaser Fawzy ABDEL-MONAIM ${ }^{2 *}$, Yasser Mahmoud MOSTAFA ${ }^{3}$ \\ ${ }^{1}$ El-Minia University, Faculty of Agriculture, Department of Plant Pathology, Minia, Egypt \\ ${ }^{2}$ Agricultural Reserce Center, Plant Pathology Research Institute, Giza, Egypt; fowzy_2008@yahoo.com (*corresponding author) \\ ${ }^{3}$ El-Minia University, Faculty of Agriculture, Department of Horticulture, Minia, Egypt
}

\begin{abstract}
During 2010-2011 growing seasons six bacterial isolates were separated from naturally infected girasole plants tubers (Helianthus tuberosus L.) cv. 'Balady', showing soft rot, collected from experimental Farm of the Faculty of Agriculture, in El-Minia University, Egypt. Pathogenicity tests showed various virulence for the bacteria isolated from girasole tubers, found pathogenic. These organisms were characterized as rod-shaped, Gram negative, $\alpha$-methyl-d-glucoside medium, reducing substances from sucrose, phos, phatase activity and deep cavities on pectate medium. Otherwise, diagnostic tests suggested that the pathogen was Erwinia carotovora ssp. carotovora. The isolated bacteria caused soft rot of wounded tubers when inoculated into tissues. The bacterial isolates were compared for their degree of pathogenicity as well as for differences in specific symptoms, induced in different hosts. The tested isolates could infect several host ranges, such as fruits of apricot, apple, olive, lemon, squash, eggplant and potato tubers, bulbs and garlic and onion cloves, roots radish, carrot, sweet potato and rape. On the other hand, no symptoms were exhibited on pods of bean and cowpea, faba bean, fruits of pepper and tomato. The extracts of experimentally diseased girasole tubers were active in pectinase and also in caboxymethyl cellulose at $\mathrm{pH} 6$ compared to enzyme activities in healthy tissues. Also, the isolated bacteria increased the total and reducing sugars in infected tissues.
\end{abstract}

Keywords: Erwinia carotovora ssp. carotovora, girasole, pectinase and caboxymethyl cellulose, total and reducing sugars

\section{Introduction}

Jerusalem artichoke is grown primarily for tubers which can be eaten fresh or raw, cooked in appetizing ways similar to Irish potatoes, or pickled. Tubers are used to fatten cattle, sheep and hogs. Stems and leaves are rich in fats, protein and pectin, making good forage and silage. The alcohol fermented from the tubers is said to be of better quality than that from sugar beets. It is good weed eradicator, as it makes so dense shade that only a few other plants can compete. It is good in ridding fields of quack grass (Margaritis and Bajpai, 1982). Bacterial post-harvest diseases affect quality and availability of fruit and vegetable (Wells et al., 1993). Bacterial pathogens, involved in this respect, include the soft-rotting species of Erwinia, Pseudomonas, Xanthomonas, Cytophaga and Bacillus (Liao and Wells, 1987; Lund, 1983).

Plant diseases caused by plant pathogens mean a complicated process because the number of factors playing part. However, direct involvements of pectic and cellulitic enzymes, produced by the pathogen in pathogensis, were reported (Gaber et al., 1990; Walker et al., 1994). Bacteria soft-rot caused by Erwinia carotovora ssp. carotovora (Van Hall), Dye, is one of the most important and widespread bacterial disease of a wide variety plants, either in the field or during storage (Hajhamed et al., 2007).
The objective of this investigation is to isolate and identify the pathogenic agent, involved or associated, soft-rot disease of girasol tubers at El-Minia governorate. Furthermore, the cell wall degradation enzymes in pathogenesis were discussed.

\section{Materials and methods}

\section{Isolation}

Infected girasole tubers showing typically developed soft-rotting (Fig. 1) were subjected for isolation. During 2010 growing season samples of girasole tubers' rot (cv. 'Balady') were collected from experimental Farm of the Faculty of Agriculture, Department of Horticulture, ElMinia University, and isolation of the microorganisms, associated with these symptoms, was conducted. Diseased tubers were firstly washed with tap water then surface sterilized with $3 \%$ sodium hypochlorite solution $(\mathrm{NaOCl})$ for $3 \mathrm{~min}$, then washed thoroughly 3 times with sterilized water, the rotted tissues of tuber were put into sterilized mortar and homogenized, then left to stand for $20 \mathrm{~min}$, being streaked into plates containing crystal violet pectate modified (CVPM) medium (Ahmed et al., 2000). The plates were incubated at $27 \pm 1^{\circ} \mathrm{C}$ for $48-72$ hours. Only bacterial colonies in deep cavities (Fig. 2) were subcultured onto 
76

King's B medium and nutrient agar (NA) medium then stored on slants till they were used.

\section{Identification of the causal pathogen}

Six bacterial isolates, e.g. EC1, EC2, EC3, EC4, EC5 and EC6, were identified by studying their morphological, physiological and biochemical characters as recommended by Breed et al. (1974), Sneath et al. (1986), Lelliott and Stead (1987), Klement et al. (1990).

\section{Pathogenicity tests on girasole tubers}

The pathogenicity of the bacterial isolates was determined by inoculating intact, unblemished, healthy tubers. Each isolate was used to inoculate 5 tubers. A $1-\mathrm{cm}$ wound was made in the middle of each tuber for inoculation by smearing the inside of the wound with an entomological needle, filled with 48 hour-old cultures of the bacterial isolates, individually grown on NA medium. The inoculated tubers (cv. 'Balady') were kept in sterilized boxes, containing one piece of cotton, saturated with sterilized water, to insure high humidity. These boxes were incubated at $25 \pm 1^{\circ} \mathrm{C}$ for seven days, rot quantity and rot severity being then assayed.

The amount of rotten tissue produced in each tuber was determined and the percentage of rotten tissue was calculated, and taken as criterion of pathogenicity for each isolate. Every tuber was weighted before and after removing the rotten portion, then calculation was done according to Kelman and Dickey's formula (1980) as follows:

Rot severity $=(\mathrm{W} 1-\mathrm{W} 2) / \mathrm{W} 1 \times 100$

Where, W $1=$ weight of whole tuber and W2= weight of tuber after removal of the rotten tissue.

\section{Host range}

The highly pathogenic isolate EC1, of the causal pathogen, was inoculated into 16 plant species as listed in Tab. 1. Five plants were used in each treatment. Control treatments were similarly tested with sterile water only and kept at the same conditions. Disease severity was recoded after 7 days as above.

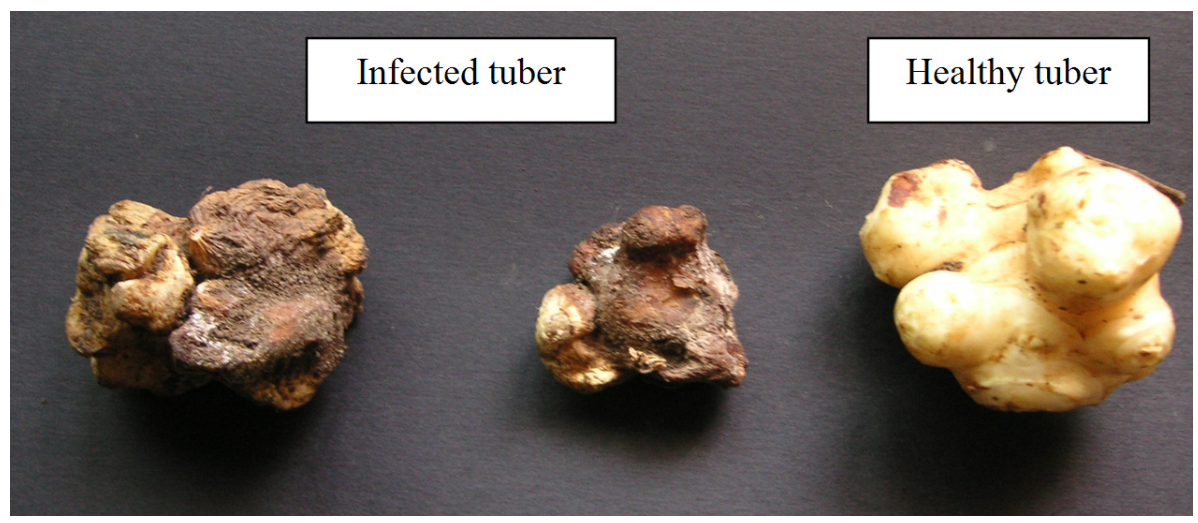

Fig. 1. Naturally infected soft-rot on girasole tubers cv. 'Balady' infected by Erwinia carotovora ssp. carotovora (left infected and right healthy tuber)

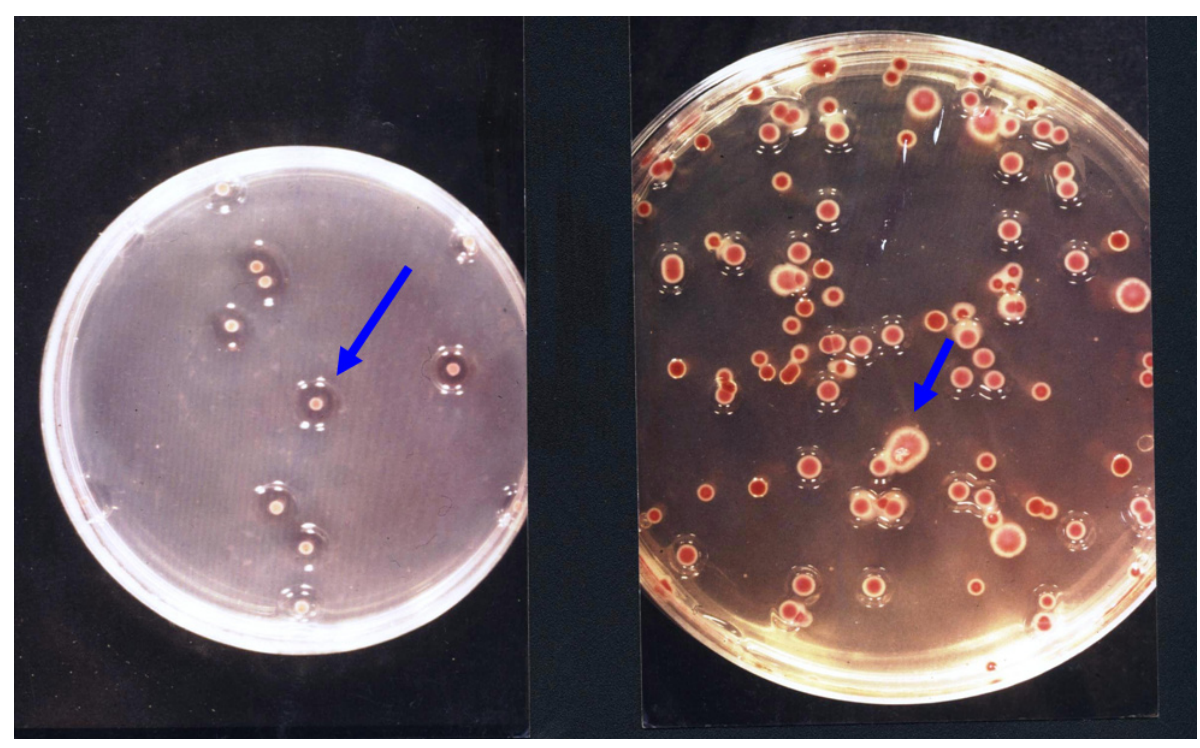

Fig. 2. Cavity formation by soft-rot bacteria after incubation at $27^{\circ} \mathrm{C}$ for 24 hours on the CVPM medium (left) and recovery of soft-rot bacteria from artificially inoculated tubers after 24 hours (right) 
Tab. 1. List of plant species tested for their reaction to Erwinia carotovora ssp. carotovora pathogen

\begin{tabular}{|c|c|c|c|c|}
\hline Hosts (Common name) & Scientific name & Family name & Variety & Part organ \\
\hline Apricot & Prunus aremeniaca & Rosaceae & 'Canino' & Fruits \\
\hline Bean & Phaseolus vulgaris & Leguminosae & 'Contender' & Pods \\
\hline Carrot & Daucus carota & Umbelliferae & 'Chantinay' & Storage roots \\
\hline Cowpea & Vigna unguiculata & Leguminosae & 'Black eye' & Pods \\
\hline Cucumber & Cucumis sativus & Cucurbitaceae & 'Balady' & Fruits \\
\hline Eggplant & Solanum melogena & Solanaceae & 'Black Beauty' & Fruits \\
\hline Lemon & Citrus limon (L.) Burm & Rutaceae & 'Balady' & Fruits \\
\hline Tobacco & Nicotiana tabacum & Solanaceae & 'Samsun' & Leaves \\
\hline Pepper & Capsicum frutesences & Solanaceae & 'Romy' & Fruits \\
\hline Radish & Raphanussativus & Carucifera & 'Balady' & Storage roots \\
\hline Onion & Allium cepa & Amaryllidaceae & ‘Giza 20’ & Storage onions \\
\hline Squash & Cucurbitapepo & Cucurbitaceae & 'Eskandarani' & Fruits \\
\hline Sweet potato & Ipomea batatas & Convolvulaceae & 'Balady' & Storage roots \\
\hline Potato & Solanm tuberosum & Solanaceae & 'Diamant' & Tubers \\
\hline Tomato & Lycopersicon esculentum & Solanaceae & 'Super strain B' & Fruits \\
\hline Turnip & Brassica rape & Carucifera & 'White globe' & Storage roots \\
\hline
\end{tabular}

Assessment of some hydrolytic enzymes (cellulase and pectinase) in diseased and healthy girasole tubers

Assessment of pectinase and cellulase enzymes were assayed in tissue extracted from diseased and healthy tuber taken from the subjected plants during pathogenicity test.

Half gram of either healthy and/or infected rot tissues were existed and separately macerated with sterilized mortar containing $5 \mathrm{ml}$ of $0.05 \mathrm{M}$ phosphate buffer $(\mathrm{pH}$ 6). The homogenated tissue extracts were filtered through two layers of cheese-cloth, cooled to temperature near zero then centrifuged at $5000 \mathrm{rpm}$ for $20 \mathrm{~min}$. The clarified enzyme preparation of healthy and infected tissues was directly subjected to the viscometric assessment according to Mahadevan and Sridhar (1982).

Total carbohydrate and reducing sugars in healthy and artificially inoculated girasole tubers:

\section{A) Total carbohydrates}

The phenol-sulphuric acid method was used to determine the total sugars in clarified tissue extract as described by Hodge and Horfreir (1962).

\section{B) Determination of reducing sugars}

This was performed according to the methods of Somogyi (1952).

\section{Statistical analysis}

All experiments were performed twice. Analyses of variance were carried out using MSTAT-C program version 2.10 (1991). Least significant difference (LSD) was employed to test for significant difference between treatments at $\mathrm{P} \leq 0.05$ (Gomez and Gomez, 1984).

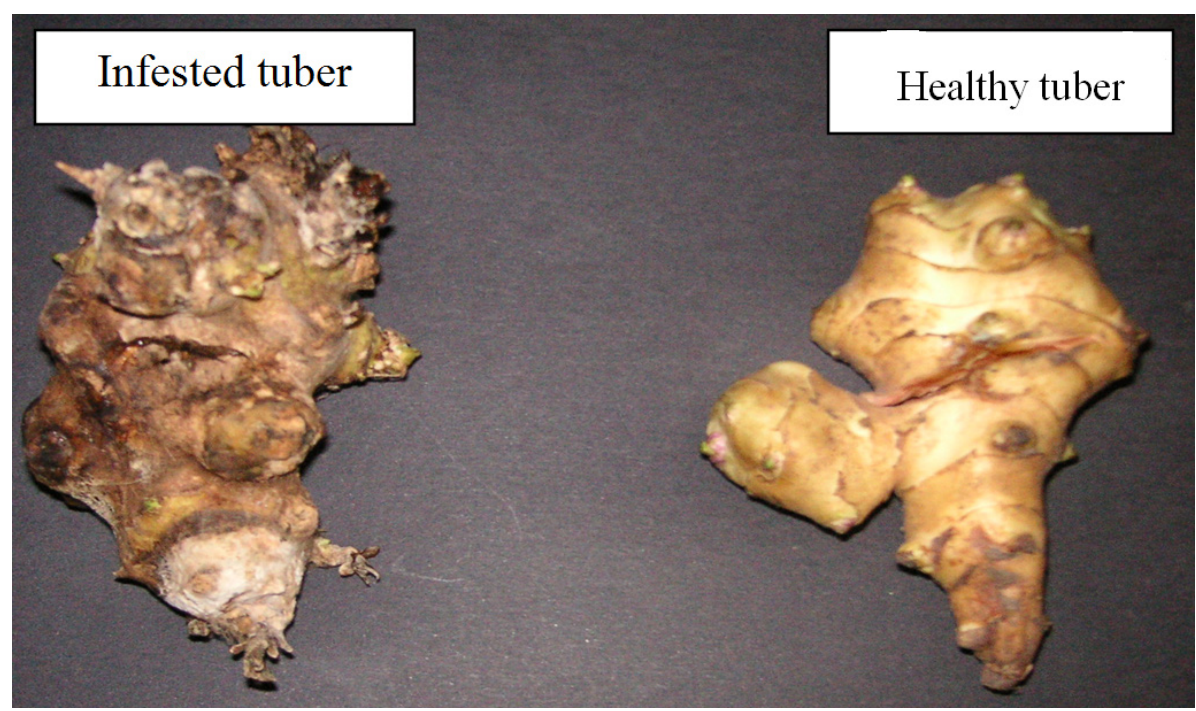

Fig. 3. Artificially infested soft-rot on girasole tubers cv. 'Balady', infected by Erwinia carotovora ssp. carotovora (left infected and right healthy tuber) 
Tab. 2. Morphological, biochemical and physiological characters of bacterial isolates

\begin{tabular}{|c|c|c|c|c|c|c|c|}
\hline \multirow{2}{*}{ Test } & \multicolumn{6}{|c|}{ Bacterial isolates } & \multirow{2}{*}{ Bradbury (1986) } \\
\hline & Ec1 & Ec2 & Ec3 & Ec4 & Ec5 & Ec6 & \\
\hline Shape & Rod & Rod & Rod & Rod & Rod & Rod & Rod \\
\hline Motility & + & + & + & + & + & + & + \\
\hline Gram reaction & + & + & + & + & + & + & - \\
\hline Pigment on $\mathrm{CaCO}_{3}$ agar & - & - & - & - & - & - & - \\
\hline Sporulation & + & + & + & + & + & + & - \\
\hline Potato slices & - & - & - & - & - & - & + \\
\hline Aerobiosis & + & + & + & + & + & + & $\mathrm{F}$ \\
\hline Gelatin liquefication & + & + & + & + & + & + & + \\
\hline Catalase production & + & + & + & + & + & + & - \\
\hline Levan production & - & - & - & - & - & - & - \\
\hline Indole formation & + & + & + & + & + & + & - \\
\hline Tolerance 5 , and $7 \% \mathrm{NaCl}$ & + & + & + & + & + & + & + \\
\hline Maximum temperature & 35 & 35 & 35 & 35 & 35 & 35 & 30 \\
\hline Utilization of sugars from Arabinose & - & - & - & - & - & - & ? \\
\hline Galactose & + & + & + & + & + & + & + \\
\hline Glucose & + & + & + & + & + & + & ? \\
\hline Lactose & + & + & + & + & + & + & + \\
\hline Fructose & + & + & + & + & + & + & $\mathrm{D}$ \\
\hline Insitol & + & + & + & + & + & + & + \\
\hline Maltose & + & + & + & + & + & + & - \\
\hline Mannitol & + & + & + & + & + & + & $?$ \\
\hline Mannose & + & + & + & + & + & + & $?$ \\
\hline Sorbitol & + & + & + & + & + & + & $?$ \\
\hline Trehalose & + & + & + & + & + & + & + \\
\hline Celliobiose & + & + & + & + & + & + & + \\
\hline Xylose & + & + & + & + & + & + & $?$ \\
\hline Raffinose & + & + & + & + & + & + & + \\
\hline Sucrose & - & - & - & - & - & - & - \\
\hline
\end{tabular}

$+=$ all isolates are positive,$(+)=$ weakly reaction, $-=$ negative reaction, $\mathrm{D}=$ isolates differed, $\mathrm{F}=$ facultative anaerobic and $?=$ isolates not tested

\section{Results and discussion}

\section{Isolation and identification of the causal organisms}

Six isolates of creamy-white bacteria were isolated from girasole plants showing typical tuber rot symptom (Fig. 1). Regardless of some slight differences, in certain characteristics, all bacterial isolates appeared to be representative of Erwinia carotovora ssp. carotovora (Tab. 2) according to the description of Bergeys Manual of Determinative Bacteriology (1974), also in the Bergeys Manual of Systematic Bacteriology (Sneath et al., 1986). However, the tests were carried out as described by Lelliott and Stead (1987) and Klement et al. (1990). The results in the present work revealed that all the tested bacterial isolates are rod-shaped, motile, Gram negative, non-spore forming, growing at $35^{\circ} \mathrm{C}$, facultative anaerobic and negatively reacted with phosphatase production, indol formation, and $\mathrm{H}_{2} \mathrm{~S}$ production. They positively reacted toward gelatine liquefaction, rot of potato and carrot slices, grown in presence of $5 \% \mathrm{NaCl}$, nitrate reduction decreased. All the tested isolates produce deep cavities semi-selective
(CVPM) medium. Otherwise, the bacterial isolates utilized glucose, galactose, fructose, cellubiose, lactose, mannitol, raffinose, trehalose, mannose and xylose but they did not utilize arabinose, maltose, sorbitol, sucrose and methy glucoside. Comparison of the isolated bacteria's characters with those reported by Dye et al. (1980), Dickey (1981) resulted their identification as being Erwinia carotovora ssp. carotovora.

Tab. 3. Pathogenicity of Erwinia carotovora ssp. carotovora on girasole tubers

\begin{tabular}{ccc}
\hline Isolates & $\begin{array}{c}\text { Rot weight } \\
(\mathrm{gm})\end{array}$ & $\begin{array}{c}\text { Rot severity } \\
\text { (\% rotted tissues) }\end{array}$ \\
\hline Ec1 & $1.40^{\mathrm{a}}$ & 92.0 \\
Ec2 & 0.99 & 41.3 \\
Ec3 & 1.23 & 74.6 \\
Ec4 & 0.89 & 23.6 \\
Ec5 & 0.68 & 21.3 \\
\hline Ec6 & 1.07 & 57.3 \\
L.S.D. at 5\% & 0.12 & 5.88 \\
\hline
\end{tabular}

${ }^{\mathrm{a}}$ Mean of five replicates; calculated as percentage of rotted tissues 
Tab. 4. Symptoms' expression with 6 bacterial isolates of Erwinia carotovora ssp. carotovora on different hosts

\begin{tabular}{|c|c|c|c|c|c|c|c|}
\hline \multirow{2}{*}{ Hosts Bacterial isolates } & \multirow{2}{*}{ Site of inoculation } & \multicolumn{6}{|c|}{ Erwinia carotovora ssp. carotovora isolates } \\
\hline & & Ecl & Ec2 & Ec3 & Ec4 & Ec5 & Ec6 \\
\hline Apricot & Fruits & $+{ }^{a}$ & + & + & + & + & + \\
\hline Bean & Pods & - & - & - & - & - & - \\
\hline Carrot & Storage root & + & + & + & + & + & + \\
\hline Cowpea & Pods & - & - & - & - & - & - \\
\hline Cucumber & Fruit & + & + & + & + & + & + \\
\hline Eggplant & Fruits & - & - & - & - & - & - \\
\hline Lemon & Fruits & + & + & + & + & + & + \\
\hline Tobacco & Leaves $^{b}$ & + & + & + & + & + & + \\
\hline Pepper & Fruits & - & - & - & - & - & - \\
\hline Radish & Storage roots & + & + & + & + & + & + \\
\hline Onion & Leaves & + & + & + & + & + & + \\
\hline Squash & Fruits & + & + & + & + & + & + \\
\hline Sweet potato & Storage roots & - & - & - & - & - & - \\
\hline Potato & Tubers & + & + & + & + & + & + \\
\hline Tomato & Fruits & - & - & - & - & - & - \\
\hline Turnip & Storage root & + & + & + & + & + & + \\
\hline
\end{tabular}

${ }^{a}$ Data are means of 5 replicates per treatment; ${ }^{b}$ Hypersensitive reaction $(\mathrm{HR})$

\section{Pathogenicity tests}

Data presented in Tab. 3 indicate that all bacterial isolates, under investigation, were able to infect girasole tubers and induce soft-rot, although they varied in severity of initiated rot. Inoculation with any of these isolates showed disease symptoms appearing soft-rot at wounded sites, and eventually collapsed within two weeks. However, the control plants remained unaffected. Soft rot symptoms (Fig. 3) sites of inoculation were obvious after 5 to 10 days from the inoculation, whereas after 10 to 15 days, the tubers were collapsed. Amount of rotting, also rated from $22.2 \%$ and $42.2 \%$ after 21 days from incubation. Also, the obtained results indicate that isolate Ec1 and Ec3 could be considered as highly pathogenic, whereas other isolates were weakly virulent. Several authors reported that Erwinia chrysanthemi and Erwinia carotovora ssp. carotovora were isolated from different plants and caused soft-rot diseases (Hajhamed et al., 2007; Liu et al., 2002; Scortichini and Dascenzo, 2003).

\section{Host range}

Results in Tab. 4 show that all isolates produced softrot on most different plants tested. On the other hand, the

Tab. 5. Effect of extract of diseased girasole tubers on percentage of $1 \%$ citrus pectin solution's viscosity during incubation for 3 hours at room temperature

\begin{tabular}{ccccccc}
\hline \multirow{2}{*}{$\begin{array}{c}\text { Time } \\
(\mathrm{min})\end{array}$} & \multicolumn{5}{c}{ \% Loss in viscosity of 1\% citrus pectin } \\
\cline { 2 - 7 } & Ec1 & Ec2 & Ec3 & Ec4 & Ec5 & Ec6 \\
\hline 0.0 & $6.8^{\mathrm{a}}$ & 5.4 & 5.4 & 2.4 & 2.4 & 2.0 \\
30 & 19.7 & 8.2 & 13.2 & 14.5 & 6.5 & 7.1 \\
\hline 60 & 33.2 & 11.8 & 20.8 & 17.8 & 15.8 & 17.7 \\
\hline 120 & 38.0 & 21.4 & 30.4 & 21.3 & 17.3 & 23.6 \\
180 & 38.0 & 21.4 & 30.4 & 21.3 & 17.3 & 23.9 \\
\hline
\end{tabular}

${ }^{a}$ Values are mean of 3 replicates following plants are not affected by inoculated bacteria such as pods of cowpea, bean and fruits of eggplant, pepper, sweet potato and tomato.

\section{Production of pectolytic and cellulolytic activity by} Erwinia chrysanthemi, in vivo

All tested isolates were active in secreting pectolytic and cellulolytic enzymes in tuber tissues of girasole plants after 10 days from inoculation (Tab. 5 and 6), whereas the isolate Ec1 (more virulent) was higher after $180 \mathrm{~min}$ than their activities with the weakly virulent (isolate Ec5). These results confirmed those reported by Galal et al. (2002), Ouf et al. (1997), Saleh (1995). They reported that the pectolytic activity of the enzymes were higher at infected tissues than at the healthy ones.

Activity of these enzymes was higher at infected tissue than at healthy ones. Data indicated that the highest activity was shown after 2 hours incubation at room temperature. These results are generally in line with those reported by previous investigators Ouf and El-Sadek (1997), Ouf et al. (1997). Similar results were reported for Bacillus subtilis and Erwinia chrysanthemi causing soft-rot of carrot roots

Tab. 6. Effect of diseased girasole tubers' extract on percentage loss of carboxymethyl cellulose (CMC) solution's viscosity during a 3 hour incubation at room temperature

\begin{tabular}{ccccccc}
\hline & \multicolumn{5}{c}{$\begin{array}{c}\text { Loss in viscosity of 1\% carboxymethyl } \\
\text { cellulose (CMC) solution }\end{array}$} \\
\cline { 2 - 7 } Time & \multicolumn{5}{c}{ Erwinia carotovora ssp. carotovora isolates } \\
\cline { 2 - 7 } & Ec1 & Ec2 & Ec3 & Ec4 & Ec5 & Ec6 \\
\hline 0.0 & $22.7^{\text {a }}$ & 15.5 & 16.7 & 11.1 & 0.0 & 10.9 \\
\hline 30 & 35.4 & 22.1 & 23.7 & 23.0 & 12.2 & 17.8 \\
60 & 43.0 & 28.7 & 39.5 & 27.5 & 20.3 & 22.4 \\
\hline 120 & 57.4 & 36.1 & 42.6 & 32.6 & 28.9 & 33.4 \\
180 & 57.4 & 36.1 & 43.90 & 32.9 & 28.9 & 33.6 \\
\hline
\end{tabular}


80

(Kararah et al., 1985; Saleh, 1995; Saleh and Gabr, 1989; Saleh and Stead, 2003). Severin et al. (1985) reported that Erwinia carotovora pv. carotovora, E. c. ssp. atroseptica, Erwinia chrysanthemi ssp. chrysanthemi and Xanthomonas campestris pv. pelargonii (the causal pathogens of soft-rot of potato, dahlia and pelargonium, respectively) were able to produce pectinase (s) and cellulase (s) enzymes.

Generally data in Tab. 7 indicate that total carbohydrates were much higher at inoculated tissue extracts than at healthy ones particularly with isolate Ec1 (more virulent). Similar trends were obtained with reducing sugars. Data presented by Saleh (1995) indicate a similar effect of the pathogen (Bacillus subtilis and B. pumilus) on total carbohydrates at infected tissues.

Tab. 7. Total carbohydrate and reducing sugars at healthy and diseased tissue extracts of girasole plants inoculated with bacterial isolates

\begin{tabular}{ccc}
\hline Treatment & $\begin{array}{c}\text { Total carbohydrate } \\
(\mathrm{mg} / \mathrm{g} \text { fresh weight })\end{array}$ & $\begin{array}{c}\text { Reducing sugars } \\
(\mathrm{mg} / \mathrm{g} \text { fresh weight })\end{array}$ \\
\hline $\begin{array}{c}\text { Control } \\
\text { (healthy tissue) }\end{array}$ & $36.22 \pm 1.4^{\mathrm{a}}$ & $20.42 \pm 3.3$ \\
Isolate Ec1 & $95.44 \pm 3.4$ & $17.82 \pm 3.0$ \\
Isolate Ec2 & $44.13 \pm 3.2$ & $10.19 \pm 2.0$ \\
Isolate Ec3 & $82.85 \pm 2.3$ & $13.23 \pm 2.4$ \\
Isolate Ec4 & $41.17 \pm 3.0$ & $11.22 \pm 5.0$ \\
Isolate Ec5 & $35.27 \pm 1.0$ & $9.12 \pm 4.1$ \\
Isolate Ec6 & $39.12 \pm 3.0$ & $7.33 \pm 3.5$ \\
\hline
\end{tabular}

${ }^{\mathrm{a}}$ Data are means of 3 replicates \pm SD

\section{References}

Ahmed ME, Mavridis A, Rudolph K (2000). Detection of latent contamination of potato tubers by Erwinia spp. using a semi-selective agar medium. Phytomedizin, Mitteilung. Deut Phytomed Gesellsch 30(1):15-16.

Breed RS, Murray EGD, Smith NR (1974). Bergeys Manual of Determinative Bacteriology $8^{\text {th }}$ Ed. The Williams and Williams Company, Baltimore, 1268 p.

Dickey DS (1981). Erwinia chrysanthemi: Reaction of eight plant species to strains from several hosts and to strains of other Erwinia species. Phytopathol 71:23-29.

Dye DW, Bradbury JF, Goto M, Hayward AC, Lelliott RA, Schroth MN (1980). International standards for naming pathovars of phytopathogenic bacteria and a list of pathovar names and pathotype strains. Rev Plant Pathol 59:163-168.

Gaber MR, Saleh OI, Abo El-Fotouh E (1990). Pectolytic, cellulolytic and proteolytic activities of two isolates of Botryodiplodia theobramae. Annals Agric Sci, Fac Agric, Ain Shams Univ, Cairo, Egypt 35(1):445-457.

Galal AA, Abdel-Gawaed, TI, El-Bana AA (2002). Post-harvest decay of garlic cloves caused by Bacillus polymyxa and Fusarium moniliforme. Egypt J Microbiol 36:71-88.

Gomez KA, Gomez AA (1984). Statistical Procedures for Agricultural Research. Wiley, Interscience Publication New-
York, $678 \mathrm{p}$.

Hajhamed AA, Abd El-Sayed WM, Abou El-Yazied A, Abd-ElGhaffar NY (2007). Suppression of bacterial soft rot disease of potato. Egypt J of Phytopath 35(2):69-80.

Hodge JE, Horfreir BT (1962). Determination of reducing sugars and carbohydrates, 380-394 p. In: Methods in Carbohydrates Chemistry. Academic Press, New York.

Kararah MA, Barakat FM, Mikhail MS, Fouly HM (1985). Pathophysiology in garlic cloves inoculated with Bacillus subtilis, Bacillus pumilus and Erwinia carotovora. Egypt J Phytopathol 17(2):131-140.

Kelman A, Dickey RS (1980). Soft rot or "carotovora" group, p. 31-35. In: Schaad NW (Ed.). Laboratory Guide for Identification of Plant Pathogenic Bacteria. APS St Paul Mim. USA.

Klement Z, Rudolph K, Sands DC (1990). Methods in Phytobacteriology Akademiai, Kiado, Budapest, 568 p.

Lelliott RA, Stead DE (1987). Method in Plant Pathology. Method for the Diagnosis of Bacterial Diseases of Plants. Blackwell Scientfic Publication, Oxford, London, Edinburg, 1-216 p.

Liao CB, Wells JM (1987). Diversity of pectolytic, fluorescence pseudomonas causing soft rot of fresh vegetables at produce market. Phytopathol 77:673-677.

Liu HL, Hsu ST, Tzeng KC (2002). Bacterial soft rot of chrysanthemum cuttings: characteristics of the pathogen and factors affecting its occurrence. Plant Pathol Bull 11(3):157164.

Lund BM (1983). Bacterial spoilage, p. 219-257. In: Demis C (Ed.). Postharvest Pathology of Fruits and Vegetables, Academic Press, London.

Mahadevan A, Sridhar R (1982). Methods in Physiological Plant Pathology, Sivakami publications, India, 119 p.

Margaritis A, Bajpai P (1982). Continuous ethanol production from Jerusalem artichoke tubers. II. Use of immobilized cells of Kluyveromyces marxianus. Biotechnol Bioeng 24:14831493.

Ouf MF, El-Sadek SAM (1997). Bacterial stem rot of dieffenbachia in Egypt. Egypt J Microbiol 32(2):269-281.

Ouf MF, El-Sadek SAM, Abdel-Latif MR, Abd El-Aziz N (1997). Pectolytic and cellulolytic activity of enzymes by Erwinia dieffenbachia, causing stem soft rot on dieffenbachia plants. Egypt J Microbiol 32(1):99-115.

Saleh OI (1995). Identification of phytopathogenic bacteria associated with post harvest disease of garlic cloves in relation to cell wall degrading enzymes. Egypt J Microbiol 30:177-202.

Saleh OI, Stead D (2003). Bacterial soft rot disease of pea in Egypt. Integrated control in protected crops, Mediterranean climate IOBC WPRS Bulletin 26(10):115-120.

Saleh OI, Gabr MR (1989): Studies on core rot of carrot in relation to cell wall-degrading. Minia J Agric Res Develop 11:1713-1722. 
Scortichini M, Dascenzo D (2003). New bacterial diseases striking ornamentals. Colture Protelle 32(5):81-84.

Severin V, Kupferberg S, Zurini I (1985). Plant Pathogenic Bacteria. Editura Ceres, Bucharest, Romania, 1-218 p.

Sneath PHA, Mair NS, Sharpe ME, Holt JG (1986). Bergeys Manual of Systematic Bacteriology. Williams Wilkins Co., Baltimore, $1123 \mathrm{p}$.

Somogyi M (1952). Notes on sugar determination. J Biol Chem 195:18-23.
Walker DS, Reeves PJ, Salmond GP (1994). The major secreted cellulose, Cel V, of Erwinia carotovora ssp. carotovora is an important soft rot virulence factor. MPMI 7(3):425-431.

Wells JE, Butterfield JE, Revear LG (1993). Identification of bacteria associated with postharvest diseases of fruits and vegetables by cellular fatty acid composition: An expert system for personal computers. Phytopathol 83:445-455. 